DEPARTMENT OF ECONOMICS

Transport policy competition between governments: A selective survey of the literature

Bruno De Borger \& Stef Proost

\author{
UNIVERSITY OF ANTWERP \\ Faculty of Applied Economics \\ Stadscampus \\ Prinsstraat 13, B.226 \\ BE-2000 Antwerpen \\ Tel. +32(0)32654032 \\ Fax +32(0)3 2654799

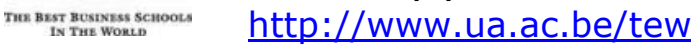




\section{FACULTY OF APPLIED ECONOMICS}

DEPARTMENT OF ECONOMICS

Transport policy competition between governments:

A selective survey of the literature

Bruno De Borger \& Stef Proost

RESEARCH PAPER 2012-014

JULY 2012

University of Antwerp, City Campus, Prinsstraat 13, B-2000 Antwerp, Belgium
Research Administration - room B.226
phone: (32) 32654032
fax: (32) 32654799
e-mail: joeri.nys@ua.ac.be

The papers can be also found at our website:

www.ua.ac.be/tew (research > working papers) \&

www.repec.org/ (Research papers in economics - REPEC)

$D / 2012 / 1169 / 014$ 


\title{
Transport policy competition between governments: a selective survey of the literature (*)
}

\author{
Bruno De Borger \\ Stef Proost
}

\begin{abstract}
In this paper, we provide a selective survey of the recent literature that deals with transport policy competition between governments. The paper shows the potential relevance of strategic behaviour by governments in deciding on prices (taxes, tolls) and investment in infrastructure capacity. The severity and the welfare effects of tax exporting behaviour and of horizontal tax and expenditure competition strongly depend on whether the transport links controlled by the different governments are strategic complements or substitutes. The scarce transport economics literature on vertical competition between hierarchical governments has so far mainly focused on the question which government level should be responsible for providing and financing local infrastructure. The survey identifies a number of gaps in the literature that may be useful avenues for further research. These include more detailed analysis of the implications of vertical tax and expenditure competition between hierarchical government levels, a political economy approach to problems of transport decision-making with multiple government levels and, most importantly, more empirical analysis to document the relevance of the theoretical literature.
\end{abstract}

JEL codes: R48,H71,H21

(*) Bruno De Borger: Department of Economics, University of Antwerp; Stef Proost: Center for Economic Studies, University Leuven, Belgium. We are grateful to two referees for many detailed comments on a previous version of this paper. Remaining errors are ours. 


\section{Introduction}

The outcomes on many transport markets are affected by policy decisions of several governments, and the implications of these policies strongly interact. A few examples may serve to illustrate this. Take public transport in a metropolitan area. Prices are often regulated or fixed by a metropolitan government, but its decisions are strongly influenced by the federal government's subsidy policies and by infrastructure policies of neighbouring jurisdictions. Federal subsidies directly affect the metropolitan government's pricing behaviour; moreover, a neighbouring jurisdiction that strongly discourages car use will send more public transport passengers to the city center and force the metropolitan area to expand its public transport network. As another example, consider a cross-border highway, high speed rail line or canal. Private operators may price and maintain the different national sections, but ultimately the relevant national governments are responsible for deciding on capacity of the infrastructure, and on the pricing or tolling contracts. Furthermore, the volume of international traffic on one segment of the cross-border infrastructure will be the result of the toll and investment decisions on both sides of the border. Still another example is the tax on gasoline, one of the main drivers of the volume and fuel efficiency of car use. Taxes on gasoline in federal countries like the US and Canada consist of both federal and state taxes. This gives rise to complex interactions: an increase in the federal gasoline tax reduces the state tax bases for gasoline; furthermore, each of the states may undercut the tax of its neighbours by offering a slightly lower tax to attract more revenue.

Governments care for the well-being of their citizens, but they are also interested in potential tax and toll revenues; moreover, they are concerned about the expenditures on infrastructure and the associated maintenance costs implied by their investment decisions. The policy instruments governments can use include prices, the provision of infrastructure capacity, and regulation (such as licences, driving bans, speed restrictions,...). This gives rise to a broad range of direct and indirect policy interactions. An example of the former is the case where one transport trip is taxed by several governments (for example, through state and federal fuel taxes). Alternatively, keeping prices constant, a change in infrastructure capacity will affect directly the transport conditions when citizens of neighbouring jurisdictions use this infrastructure. Indirect interaction occurs, for example, when the tax on certain 
transport trips (for example, public transport coming into the city) affects the generalized cost or quality of other transport trips (local car trips, local public transport trips) that are either not taxed at all or taxed by a different government.

Over the last decade the transport economics literature has paid much attention to the policy interaction between different governments, and the main purpose of this paper is to survey some of this work. The approach we take implies two main limitations. First, although we will occasionally refer to the competition between private operators for purposes of comparison -- or whenever this facilitates the interpretation of results --, the focus is on government behaviour. Second, we largely emphasize decisions on pricing and infrastructure expenditures; we will pay much less attention to purely regulatory issues ${ }^{1}$.

The paper is organized as follows. Section 2 first introduces the main issues of multi-government problems that have been dealt with in the public economics literature. Section 3 introduces and puts some structure on the most important tax and expenditure interactions in the transport sector. In Sections 4 and 5 we then provide a selective survey of the literature on transport decisions with multiple governments; to structure the discussion, we deal with horizontal and vertical government competition separately. Finally, Section 6 concludes with avenues for future research.

\section{$\underline{\text { 2. Approaches to multi-level government issues }}$}

Of course, problems of competition among governments and the potential need for policy coordination are not specific to the transport domain. A substantial theoretical literature in public economics has been developed to deal with such issues. In this section, we briefly summarize some highlights of this literature. We follow the distinction typically made between the "normative" and the "political economy" approach. In the normative approach, one assumes that federal, regional and metropolitan governments maximize a weighted sum of the utility of the voters of their constituency. The political economy approach specifies the public decisionmaking process itself in more detail, emphasizing the role of voting rules, political

\footnotetext{
${ }^{1}$ Pricing is to be interpreted in a broad sense, including road pricing, congestion tolls, fuel taxes, etc. The literature has in general focused much more on pricing than on regulation. Regulatory measures span a wide variety of measures, ranging from traffic bans to speed restrictions. One of the reasons for why the literature has not intensively studied regulatory measures may be that some of these measures can be translated into price or cost equivalents: for example, one way to reduce congestion caused by foreign trucks is to use a complex licensing system.
} 
rents and interests groups. Although some public decision processes produce a result that can be represented by a weighted sum of voters' utility functions, often many other mechanisms are at work.

This section will not only be useful to understand how transport applications fit in into this broader literature, it will also provide a first indication of what are some major gaps in the existing literature on transport policies with multiple governments. Specifically, the survey in Sections 4 and 5 below will illustrate that there is a clear lack of studies analysing transport problems from a political economy viewpoint.

\subsection{The normative approach to multi-level government}

At the risk of oversimplifying an impressive literature, the normative approach deals with at least two questions that are directly relevant to transport problems. A first question originates in the seminal work of Oates (1972); for a recent update, see Boadway and Shah (2009). The question is what the appropriate level of decision-making is for the provision of public goods. Starting from the view that a federal government can only implement a level of local public goods that is uniform over all regions, one of the major benefits of leaving the authority on the supply of local public good to the regions is that the level of supply can be adjusted to the preferences of local users (the preference-matching argument). So the more diversified are the preferences for local public goods, the higher will be the welfare gain of decentralising decisions to the regions. When individuals change residence very easily, they could end up in internally homogenous regions, and this intensifies the gain of decentralisation (Tiebout,1956). Three side conditions determine the relative efficiency of the decentralised supply of public services. First, when there are strong economies of scale in providing the public good, regional supply may be too costly. Second, when there are positive (negative) spill-overs to other regions, the non-cooperative equilibrium will generate a too low (too high) supply of the good. Third, a supply of public goods by the public sector requires public revenues that are collected in an efficient way from the local population.

The issue just raised is directly relevant in transportation; for example, what government level should be responsible for deciding on, and financing of, particular types of infrastructure? Related to this issue, a second topic extensively analysed in the literature is the problem of generating public funds through taxation. A multigovernment setting gives rise to both horizontal and vertical tax interactions (for 
detailed introductions and early surveys of this literature, see Dahlby (1996) or Wilson (1999)). Horizontal interactions exist when the tax base is mobile between different jurisdictions. This makes the use of such tax bases more difficult, as they tend to escape to the jurisdiction with the lowest tax rate. Vertical interactions exist when several layers of government impose taxes on the same tax base. As each government ignores the loss of tax revenues for other layers of government when it increases its tax level, this could lead to inefficiently high tax rates because of double marginalization. Both issues are relevant in the transport sector, see Section 3 below.

\subsection{The political economy approach}

More recently, the claim of the normative approach that decentralisation is beneficial because of better preference matching and better accountability of local government has been analyzed in more detail using a political economy approach ${ }^{2}$. The assumption that federal supply of public goods is uniform over regions turns out to be empirically invalid, and political power can be used at the federal level to favour certain regions ${ }^{3}$. In order to understand the implications of federal versus local command of expenditures on local public goods, it is crucially important to specify how the public decision-making mechanism works at the central level. Besley (2005) sets out a general structure of the public decision-making process as a principal-agent problem in which the population tries to induce politicians and public agencies to select policies that are most beneficial for voters. This not only raises the issue of aggregation of preferences, it also implies problems of asymmetric information (agencies and politicians know more than voters). These include adverse selection that may lead bad politicians or officials to be elected in office (see, e.g., Caselli and Morelli (2004)).

In a classic paper Besley and Coate (2003) focus on two specific approaches to model centralized decision-making. The first one is based on the legislative bargaining mechanism developed by, among others, Baron and Ferejohn's (1989). It assumes perfect information and, once parliament has taken its decision, perfect control of politicians and the executing agencies. The idea is as follows. Assume there are $n$ homogenous regions of the same size. Each region has one representative at the federal level, and each representative has an equal probability to become agenda

\footnotetext{
${ }^{2}$ See Lockwood (2006) for a survey.

${ }^{3}$ As demonstrated by Knight for US motorways (2004).
} 
setter. The agenda setting representative $j$ has to propose a vector of local public goods $\left(x_{1}, x_{2}, \ldots ., x_{j}, \ldots \ldots . x_{n}\right)$ that has to be accepted by a majority against the alternative $(0,0, \ldots, 0, \ldots .0)$. All regions share equally in the total cost of supplying the local public good. Under the specified conditions, agenda setter $j$ will propose a

minimum winning coalition. This is a coalition that forms a majority by supplying only public goods in those regions that are cheap to satisfy. Of course, centralized decisions by a minimum winning coalition lead to inefficiencies, because they allow the agenda setter to supply extra local public goods in his own region $j$ and still have a majority that prefers the costly and asymmetric bundle he proposes rather than the alternative. A second approach considered by Besley and Coate (2003) is to assume a cooperative legislature that maximizes the surplus of its members. Although the legislature is now assumed to be benevolent, this political decision-making process also implies inefficiencies. It may lead to strategic delegation, in the sense that regions may delegate members to the legislature with a high preference for public spending. This leads to inefficiently large spending on public services at the central level.

It is clear that a political economy approach to public transport decisions involving multiple governments may yield relevant insights. For example, how do countries decide on toll and capacities, and what are the outcomes to be expected from the political process? What policy instruments are more likely to be observed, and why? How are federal infrastructure funds allocated in federal states? Unfortunately, the literature on the underlying political economy of transport decision-making is scarce. We return to this issue in Section 6 below.

\section{Fiscal externalities in transportation: a quick overview}

It is widely known that transport activities generate externalities (pollution, congestion, etc.) that to some extent spill-over to other regions or countries. Trucks operating abroad not only suffer from time losses due to congestion on the foreign network, they also contribute to this congestion. At the same time, the emissions generated by both domestic and international trucking services in a given country partially spill over to other countries. Importantly, however, to these traditional externalities we have to add fiscal externalities: when, in a country or region, 
transport activities of non-residents generate tax revenues or require subsidies, this affects the well-being of local residents. Governments are aware of this so that, when making transport pricing and capacity decisions, they will take such fiscal externalities into account. They may even pay much more importance to the fiscal revenue effects than to the other, sometimes less visible (for example, pollution), externalities.

Table 1 lists some of the fiscal and expenditure externalities in transportation; both horizontal and vertical externalities are considered. We start by making abstraction of pollution and congestion, as this allows us to make a direct link with the fiscal federalism literature. Note that the severity of the impact of specific fiscal externalities itself will strongly depend on the mobility of the tax base, and therefore on the specific tax instruments used. For example, if a country uses fuel taxes as one of the main pricing instruments, tax competition may largely dominate tax exporting, especially in small open economies. However, tax exporting may become much more relevant if road tolls are used in large countries.

The speculative predictions of the implications of different fiscal externalities we report in Table 1 are based on the extensive public economics literature dealing with the efficiency consequences of horizontal and vertical tax competition, and on the resulting tax rates and levels of public service supply. With horizontal competition between countries or regions, it has been shown that tax exporting leads jurisdictions to either tax discriminate against non-residents or to excessively tax goods that are to a large extent consumed by non-residents (see, e.g., Arnott and Grieson (1981) or Dahlby (1996)). Tax competition induces jurisdictions to compete for the mobile tax base. If capital is the mobile factor, many papers (e.g., Bucovetsky and Wilson (1991), Wildasin (1988); see the survey in Wilson (1999)) suggest that tax competition puts downward pressure on tax rates and yields too low a level of public good supply. Intuitively, when a country raises its tax rate it treats capital outflow as a cost, and it ignores the benefits to other regions. Models of commodity taxation in an international setting confirm the inefficiency of tax competition ${ }^{4}$. Within a general

\footnotetext{
4 Note that several papers have pointed at the possibilities for welfare-improving tax competition. First, competition to attract firms (through subsidies) may be efficient (Black and Hoyt (1989)) if it induces efficient firm location. Second, imperfectly competitive markets may make tax competition efficient: if firms choose location, tax competition for firms eliminates wasteful subsidies to exports (Janeba (1998)). Third, tax competition also solves the government's commitment problems with respect to, e.g., capital investments. In the absence of tax competition, if governments determine taxes
} 
equilibrium framework, Mintz and Tulkens (1986) showed that tax rates are generally too low, with under provision of public services as a direct consequence. Kanbur and Keen (1993) studied tax competition in a partial equilibrium model of cross-border shopping with asymmetric regions in which the objective of regions is the maximisation of tax revenues. They showed that, at the Nash equilibrium, the small country undercuts the large country, and that the former may substantially benefit from tax competition. This is simply because of the high elasticity of tax revenues with respect to the tax rate: a low tax rate generates substantial extra revenues (see, e.g., fuel tax policy in Luxemburg) ${ }^{5}$.

Vertical tax competition between a higher and lower level of government may result if tax policies of one level of government affect tax revenues at another level due to, e.g., sharing of tax bases. The associated inefficiencies depend on whether governments are benevolent or not (welfare maximising or revenue maximising), on whether the game is Nash or Stackelberg, and on the existence of limits on the available tax instruments. Assume benevolent governments and suppose the federal government is interested in 'correcting' vertical inefficiencies at lower levels (i.e., it is the leader in a Stackelberg game; see, for example, Boadway et al (1998)). The typical argument then is that the lower level sets tax rates inefficiently high because it ignores the effect of its taxation on the tax revenues for the higher level government. One shows that the federal level can in principle undo any vertical inefficiency created by the lower level of government by combinations of taxes-subsidies and intergovernmental grants. The intuition is that the federal government as Stackelberg leader has the same objective as the local government: to maximize the welfare of the same citizens. This is the major difference with the vertical competition of private operators.

If benevolent federal and local governments move simultaneously (Nash game), Hoyt's (2001) model with identical local governments implies that the federal level cannot affect tax policies of local governments, but through its own choice of

\footnotetext{
after investments have been made, there is an incentive to set taxes high. With tax competition, however, governments must keep taxes low (see, e.g., Kehoe (1989)).

5 Tax and expenditure competition have also been compared in studies by, e.g., Wildasin (1989) and Upman (1998). It is found that, if public services benefit residents, the Nash equilibria in taxes and expenditures differ; moreover, expenditure competition turns out to be more competitive in the sense of leading to lower levels of public spending than tax competition. If public expenditures mainly benefit industries, this last result does not generally hold.
} 
tax rate on the overlapping tax base it can still induce the efficient overall tax rates. Federal grants are then used to obtain the appropriate mix of local and federal public services. These results do not hold in a system of regions where each local authority chooses its own tax rate, such as in the EU. In that case the higher level cannot restore efficiency by setting the federal tax rates, which are uniform across regions. Moreover, if the federal level cannot use grants, it will lower its tax rates to partially offset the vertical fiscal externality and reduce federal public good provision. If in addition tax bases do not fully overlap in the sense that the federal level has additional instruments, it should actually subsidize some goods that are inefficiently taxed by lower level governments.

Finally, if governments are not benevolent the implications of vertical competition drastically change. For example, if governments maximise revenues instead of welfare (Keen and Kotsogiannis (2003)) a reduction of tax rates from the Nash equilibrium levels is welfare-improving and raises total tax revenues.

The public finance literature mentioned in this subsection provides crucial insights for the transport sector. Horizontal competition between regions implies that the pricing and investment decisions made by a particular region will strongly depend on how intensively the local infrastructure is used by traffic from other regions. It may lead to 'exploitation' of users from other regions, and it is inefficient. Vertical competition due to overlapping tax bases between hierarchical governments (federal versus regional, regional versus urban) will lead to excessive taxes on the same tax base, again yielding inefficient outcomes.

However, some specific characteristics of the transport sector imply that issues of tax and expenditure competition are more complex than suggested by the standard public economics literature. The most important complication is probably congestion. In the absence of pricing of the use of the infrastructure, congestion by foreign users will strongly affect investment decisions and possibly lead to excessive regulation of foreign users. In the presence of pricing, congestion will generate a different price setting behaviour than in the case of pure tax competition. Moreover, other specificities of the transport sector include environmental externalities, the network structure of the transport system, the use of local networks by both local and through traffic, the interaction between private and public provision of services, and the existence of logistic chains in transport networks. Finally, more than in other sectors operators are likely to engage into simultaneous competition in taxes and expenditures 
in cases where there are benefit spill overs from expenditures (e.g., investment in infrastructure) and where tax exporting opportunities are enhanced by local spending. For example, governments may not only compete via fuel taxes and road tolls, but they may at the same time use specific infrastructure investments as an instrument to facilitate tax competition.

In the next two sections, we present a selective review of the economic literature on policy competition in the transport sector. Consistent with Table 1, we will distinguish horizontal and vertical competition. 
Table 1 : Fiscal and expenditure competition in transportation

\begin{tabular}{|c|c|c|c|}
\hline Type & Source & Transport example & $\begin{array}{l}\text { Potential } \\
\text { implications }\end{array}$ \\
\hline \multirow[t]{2}{*}{$\begin{array}{ll}\text { Horizontal fiscal } \\
\text { externality }\end{array}$} & $\begin{array}{l}\text { Tax exporting: the } \\
\text { desire of } \\
\text { governments to } \\
\text { shift the tax burden } \\
\text { to users of other } \\
\text { regions or countries }\end{array}$ & $\begin{array}{l}\text { High taxes on } \\
\text { services or on parts } \\
\text { of the infrastructure } \\
\text { used intensively by } \\
\text { non-residents or } \\
\text { foreigners }\end{array}$ & $\begin{array}{l}\text { Too much reliance } \\
\text { on taxes borne by } \\
\text { non-residents or } \\
\text { foreigners }\end{array}$ \\
\hline & $\begin{array}{l}\text { Tax competition } \\
\text { for a mobile tax } \\
\text { base }\end{array}$ & $\begin{array}{l}\text { Low taxes on fuel } \\
\text { to generate extra } \\
\text { revenues in small } \\
\text { open economies } \\
\text { (e.g., Luxemburg) }\end{array}$ & $\begin{array}{l}\text { Downward } \\
\text { pressure on tax } \\
\text { rates }\end{array}$ \\
\hline \multirow[t]{2}{*}{$\begin{array}{l}\text { Horizontal } \\
\text { expenditure } \\
\text { externality }\end{array}$} & Benefit spill-over & $\begin{array}{l}\text { Infrastructure } \\
\text { investment }\end{array}$ & $\begin{array}{l}\text { Under-investment } \\
\text { in capacity and } \\
\text { maintenance }\end{array}$ \\
\hline & $\begin{array}{l}\text { Expenditure } \\
\text { competition }\end{array}$ & $\begin{array}{l}\text { Infrastructure } \\
\text { investment } \\
\text { attract } \\
\text { business }\end{array}$ & $\begin{array}{l}\text { Over-investment in } \\
\text { specific } \\
\text { infrastructure }\end{array}$ \\
\hline $\begin{array}{ll}\text { Vertical } & \text { fiscal } \\
\text { externality } & \end{array}$ & $\begin{array}{lr}\text { Overlapping } & \text { tax } \\
\text { bases: potential for } \\
\text { higher and lower } \\
\text { government to } \\
\text { partially tax the } \\
\text { same base }\end{array}$ & $\begin{array}{l}\text { Federal and } \\
\text { regional fuel taxes }\end{array}$ & $\begin{array}{l}\text { Excessive taxes on } \\
\text { the shared tax base }\end{array}$ \\
\hline $\begin{array}{l}\text { Vertical } \\
\text { expenditure } \\
\text { externality }\end{array}$ & $\begin{array}{l}\text { Expenditure } \\
\text { interdependence }\end{array}$ & $\begin{array}{l}\text { Spending on roads } \\
\text { by cities that affect } \\
\text { fuel tax revenues } \\
\text { for } \\
\text { authority }\end{array}$ & $\begin{array}{l}\text { Under-provision of } \\
\text { such activities }\end{array}$ \\
\hline
\end{tabular}

\section{Horizontal competition in transport: overview of the literature}

In this section, we summarize the economic literature on horizontal competition in the transport sector. This literature emphasizes the presence and potential interaction between two types of externalities: standard transport externalities such as congestion, and the prototype fiscal and expenditure externalities referred to in Table 1. To structure the discussion, we use two important assumptions from this literature as guidelines. 
First, to derive useful economic insights without having to engage in the complexity of real-world networks, the theoretical literature mainly focuses on three prototypes: parallel, serial and mixed networks ${ }^{6}$. We will do the same below. Horizontal competition on parallel and serial networks is illustrated in Figure 1. Parallel networks may describe different competing roads (e.g., a highway and another major route) or competing modes on a given transport link. Importantly, they also capture the case where (typically through) traffic has a choice between different jurisdictions' networks. For example, there are two main routes from South-Central Europe (Switzerland, Austria, and Italy) to the north (Belgium, Netherlands, etc.), one through France, the other via Germany. Or consider the transalpine crossing between Germany and Italy, where Austria and Switzerland compete for transit traffic. In both examples, transit has a choice of routes and it interacts with local traffic in each country.

Serial networks may describe highways or rail connections sequentially passing through the jurisdiction of different countries, or regional roads that pass through an urban area. The consequence is that the same traffic (for example, through traffic) can be taxed by each of the governments. Obviously, these issues are extremely relevant in practice; think, for example, of the US Highway system and the Trans European Networks (TEN's) developed within the EU. Moreover, a serial setting applies to inter-modal freight trips where the transfer facility (ports, airports, freight terminal) and the upstream or downstream infrastructure are controlled by different governments. The possibility of strategic behavior in the case of a serial corridor has been noted several times before. In the case of railroads, for example, EU Directive 2001/14 has explicitly argued that coordination between countries is needed in order to avoid the negative effects of the lack of harmonization of different charging systems used by member states ${ }^{7}$. Moreover, Nash (2005) finds some evidence of tax exporting behavior in an analysis of European infrastructure charges.

\footnotetext{
${ }^{6}$ In generalized networks, the same link can be a substitute for some users and a complement for others, and general theoretical results are difficult to derive. We therefore follow the existing literature and, admittedly somewhat artificially, explicitly distinguish serial and parallel networks. As noted by a referee, it is clear that this artificial distinction may amplify results compared to real world situations. The advantage of the distinction, however, is the transparency of the results.

${ }^{7}$ For the High Speed Rail (HSR) network between the UK, France and Belgium, separate public operating companies ("EUROSTAR" and "THALYS") have been set up. Theynot only coordinate operations, but they also share profits in order to avoid the double marginalization problems that are typical for serial networks (see Section 4.2.2).
} 
Although these simple representations are often all that is needed to study the main strategic policy issues, real world networks are an extended mixture of the various prototypes. Not surprisingly, various studies have therefore considered mixed networks, consisting of a (potentially large) number of parallel and serial sections, see below.

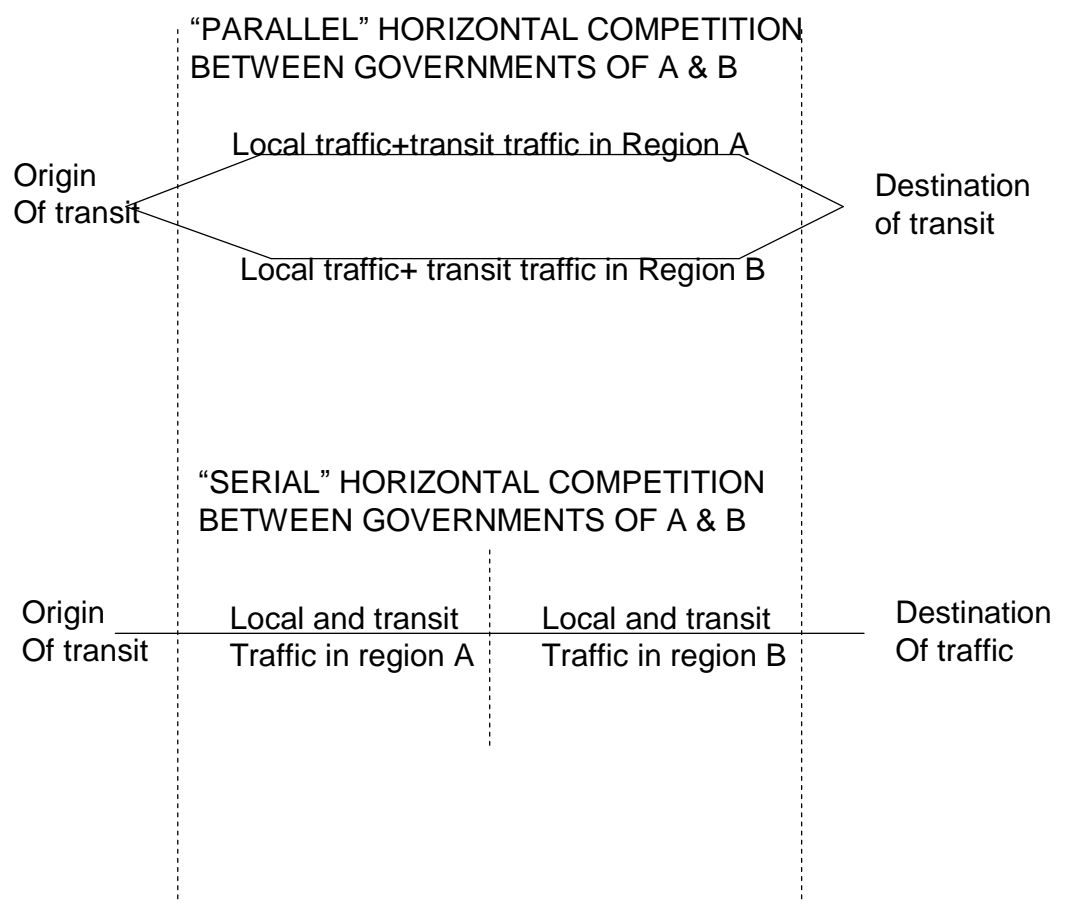

\section{Figure 1. Two types of horizontal tax competition}

Second, many governments face the problem that the local network is used both by local and non-local users: many trips are 'transit' trips that have neither origin nor destination within the government's jurisdiction (pure through traffic), others have either origin or destination within the authority's jurisdiction but not both (for example, commuters in the case of urban governments). This is also illustrated on Figure 1. This makes our problem formulation different from the competition between private operators on a network, because governments will be concerned about the welfare of local residents. However, to the extent that public authorities do price the use of the network (via fuel taxes or charges) and also care about toll revenues and capacity costs, there do remain some similarities with the behavior of private operators. For this reason, we will refer to competition between private operators whenever this facilitates the discussion of the mechanisms underlying the main results. One way of understanding many of the results described below is to see the 
different local governments as pursuing two objectives: improving transport conditions as far as their own residents are concerned and generating profit or tax revenue from through traffic.

We proceed as follows. In subsection 1, we start out by reviewing the results of studies that have analyzed how a single operator, responsible for pricing decisions (and in a few exceptional cases, investment decisions) on a simple network, will determine prices. Subsection 2 then summarizes the literature on horizontal competition on simple parallel and serial networks. In subsection 3, we report what has been learnt from models dealing with horizontal competition between logistic chains. This reflects situations where transport facilities such as ports or airports compete in an oligopolistic setting, but where each facility serves as a direct supplier to downstream firms (for example, trucking firms shipping goods between ports and hinterland). Although parts of the 'networks' considered may be privately operated, governments are typically involved in setting several of the crucial policy variables (for example, hinterland tolls, port capacities, etc.).

\subsection{Networks controlled by a single operator}

The problem of a single private or public operator fully or partially controlling a simple network consisting of two parallel roads has been explored in great detail in the literature (for a recent overview, see Small and Verhoef (2007)). We provide an overview of some of the highlights of this literature in Table 2. The table borrows the structure suggested in Ubbels and Verhoef (2008); it provides the main authors with the year of publication, the network type used, whether the network (or part of the network in case there is competition with a free access road) is controlled by government or the private sector, and whether the study looks at pricing only or also captures optimal capacity decisions.

Of course, if a welfare maximizing government can toll both routes optimally, the literature finds first-best tolls reflecting marginal external congestion costs on both routes. If there is an un-tolled route, pricing the tolled route at marginal social cost is obviously suboptimal. The optimal second-best toll typically corrects the availability of an un-tolled alternative by reducing tolls below marginal external cost (LévyLambert (1968), Marchand (1968)). The welfare gains from tolling just one route may therefore not be very large when users are homogenous (Liu and McDonald (1998)). 
They turn out to be much larger once one allows for heterogeneous users (see, for example, Small and Yan (2001), Verhoef and Small (2004)) or for variations in departure time (Braid (1996), De Palma and Lindsey (2000)).

Several papers have focused on comparing the behavior of different authorities responsible for policy decisions. For example, Verhoef, Nijkamp and Rietveld (1996) focus on different ownership regimes. They consider, among others, competition between a private road and a free-access road, and they compare the second-best optimal tolls with those obtained when both roads are privately owned. They find that it may be more efficient to have a monopolist controlling the entire network, rather than just a part of it. This will be the case, for example, if the free flow user cost of the tolled road exceeds that on the un-tolled road. More recently, De Borger and Proost (2012b) compare the behavior of different governments. They study the optimal use of various policy instruments (externality-reducing investments, tolls, emission standards, low emission zones, and bypass capacity to guide traffic around the city center) to reduce pollution-type traffic externalities in cities. They show that the city government will over-invest in externality-reducing infrastructure whenever this infrastructure increases the generalized cost of through traffic. Comparing emission standards and road tolls, they find that cities with many commuters will favor tolls, even though from the federal perspective standards are better. Finally, the city will only invest in bypass capacity when it is allowed to earn toll revenues on the bypass that exceed investment costs.

Finally, a few papers have looked at optimal pricing by a single operator (but comparing in some cases different ownership regimes) on general networks. For example, Verhoef (2002) and Van Dender (2004) study generalized networks, and Brueckner (2002, 2005), Verhoef and Small (2004) and Verhoef and Rouwendal (2004) use simple network representations with more than two links. Yang and Meng (2000) and Yang et al (2002) have studied simple mixed networks, allowing for both route choice and user heterogeneity. 
Table 2: Network models with a single operator

\begin{tabular}{|c|c|c|c|}
\hline $\begin{array}{l}\text { Authors and year of } \\
\text { publication }\end{array}$ & $\begin{array}{l}\text { Network } \\
\text { type (P: } \\
\text { parallel } \\
\text { network; } \\
\text { S: serial } \\
\text { network; } \\
\text { M: mixed } \\
\text { network) }\end{array}$ & $\begin{array}{l}\text { Control over } \\
\text { instruments } \\
\text { (G: } \\
\text { government; } \\
\text { P: private } \\
\text { firm; F: free } \\
\text { access road) }\end{array}$ & $\begin{array}{l}\text { Instruments used }(\mathbf{P}: \\
\text { pricing; C: capacity, R: } \\
\text { regulation) }\end{array}$ \\
\hline $\begin{array}{ll}\text { Lévy } & \text { Lambert } \\
(1968) & \end{array}$ & $\mathrm{P}$ & GF & $\mathrm{P}$ \\
\hline Marchand (1968) & $\mathrm{P}$ & GF & $\mathrm{P}$ \\
\hline McDonald (1995) & $\mathrm{P}$ & GF & $\mathrm{P}$ \\
\hline Viton (1995) & $\mathrm{P}$ & $\mathrm{PF}$ & $\mathrm{P}$ \\
\hline Braid (1996) & $\mathrm{P}$ & GF & $\mathrm{P}$ \\
\hline $\begin{array}{ll}\text { Verhoef, } & \text { Nijkamp } \\
\text { and } & \text { Rietveld } \\
\text { (1996) } & \end{array}$ & $\mathrm{P}$ & GPF & $\mathrm{P}$ \\
\hline $\begin{array}{l}\text { Liu and McDonald } \\
\text { (1998) }\end{array}$ & $\mathrm{P}$ & GPF & $\mathrm{P}$ \\
\hline $\begin{array}{l}\text { Liu and McDonald } \\
\text { (1999) }\end{array}$ & $\mathrm{P}$ & GF & $\mathrm{P}$ \\
\hline $\begin{array}{l}\text { Yang and Meng } \\
(2000)\end{array}$ & $\mathrm{M}$ & $\mathrm{P}$ & $\mathrm{P}$ \\
\hline $\begin{array}{l}\text { Small and Yan } \\
(2001)\end{array}$ & $\mathrm{P}$ & GPF & $\mathrm{P}$ \\
\hline Verhoef (2002) & $\mathrm{M}$ & $\mathrm{G}$ & $\mathrm{P}$ \\
\hline Brueckner (2002) & $\mathrm{M}$ & GP & $\mathrm{P}$ \\
\hline $\begin{array}{l}\text { Yang, Tang, } \\
\text { Cheung and Meng } \\
(2002)\end{array}$ & $\mathrm{M}$ & $\mathrm{P}$ & $\mathrm{P}$ \\
\hline Van Dender (2004) & $\mathrm{M}$ & $\mathrm{G}$ & $\mathrm{P}$ \\
\hline $\begin{array}{l}\text { Verhoef and } \\
\text { Rouwendal (2004) }\end{array}$ & $\bar{M}$ & GF & $\mathrm{PC}$ \\
\hline $\begin{array}{l}\text { Verhoef and Small } \\
\text { (2004) }\end{array}$ & M & GPF & $\mathrm{P}$ \\
\hline Verhoef (2007) & $\mathrm{M}$ & GPF & $\mathrm{PC}$ \\
\hline $\begin{array}{l}\text { De Borger and } \\
\text { Proost }(2012 b)\end{array}$ & $S$ & $\begin{array}{l}\text { G (urban } \\
\text { versus } \\
\text { federal) }\end{array}$ & PCR \\
\hline
\end{tabular}




\subsection{Horizontal competition between multiple operators}

In this section, we review the literature on strategic competition between operators of transport facilities. As argued by Ubbels and Verhoef (2008) and shown in De Borger, Dunkerley and Proost (2008), the welfare implications from pricing and capacity decisions may depend heavily on the network structure. We therefore first look at parallel and serial networks separately, then a brief comparison follows. A selective overview of relevant studies is given in Table 3 at the end of this section. Note that a discussion of competition between parallel logistic chains is relegated to section 4.3. Moreover, we only consider papers where governments are explicit players. For studies on network competition between private players only one can consult, among others, De Palma and Leruth (1989), Van Dender (2005), De Borger and Van Dender (2006), Xiao, Yang and Han (2007), Wu, Yin and Yang (2011), and van den Berg and Verhoef (2012).

\subsubsection{Strategic competition on parallel networks}

The first paper to formally consider strategic behavior on simple parallel road networks is due to De Palma and Lindsey (2000). Within the framework of a dynamic bottleneck model of congestion, they compare three types of ownership structure: a private road competing with a free access road, two competing private roads, and competition between a private and a public operator. They show that, if neither has a dominant share of total capacity, competition between two private road operators does not imply large welfare losses compared to first-best pricing.

Although de Palma and Lindsey (2000) does compare different ownership structures, they do not explicitly study competition between two public authorities. As many governments face the problem that the local network is used both by local and non-local users, the potential for tax exporting behavior is obvious. By raising tolls on roads that are intensively used by through traffic, governments can shift the burden mainly to outsiders. De Borger, Proost and Van Dender (2005) study this phenomenon in detail, considering competition between 2 public operators in a setting with tolls only, but distinguishing local and transit (i.e., through) traffic. They assume a simple two-road parallel network where each of the two links can be tolled by a 
different government. Transit has a choice of routes and it interacts with local traffic in each country. The paper analyses the potential tax competition between countries that each maximize the surplus of local users plus tax revenues in controlling local and transit transport. Three types of tolling systems are considered: (i) toll discrimination between local traffic and transit is allowed and feasible ${ }^{8}$, (ii) only uniform tolls on local and transit transport are acceptable, (iii) tolls on local users are the only possibility; transit remains un-tolled ${ }^{9}$.

In the case of toll differentiation, the study shows that the local and transit tolls both exceed the local marginal external cost; moreover, the transit toll is strictly larger than the local toll. To understand this, note that the results capture the role of both the congestion externality and a horizontal fiscal externality. The transit toll exceeds the local toll because of tax exporting; this still holds if there is no congestion. The local toll exceeds marginal external cost due to the interaction of local and transit demand in generating congestion. It means that the true opportunity cost of an increase in local traffic not only covers the local direct marginal external cost but also the opportunity cost of the lost tax revenues on transit. Of course, if there were no congestion, the local toll is zero.

If tolls have to be uniform, tax exporting shows up in a different form: the optimal uniform toll exceeds the local direct marginal external cost, and it rises with transit. Finally, if governments can only toll local traffic, the optimal local tax is positive but smaller than the local marginal external cost: a high toll would reduce local transport demand and, because this lowers the marginal private time cost for transit, it attracts more through traffic. In other words, if one cannot tax through traffic, one makes through traffic unattractive by having much local demand.

A numerical application yields three important insights. First, it suggests that the inability to toll through traffic strongly reduces welfare, whereas the way in which transit is tolled (differentiation of tolls versus uniform tolls) does not yield large differences in total welfare. Second, the welfare effects of cooperation between charging countries are relatively small in comparison with the total welfare gains of non-cooperative tolling of transit. In other words, it is much better for total welfare

\footnotetext{
${ }^{8}$ In practice, this can take subtle forms: for example, in Switzerland the use of the motorways by a car requires a yearly pass. The result is that tourists pay much more per trip than locals.

${ }^{9}$ This is likely to happen when the transaction costs are much higher for occasional transit users. As one example, foreign cars do not have to pay the Stockholm cordon toll.
} 
that competing countries each impose tolls on through traffic than that countries cooperate but fail to toll transit. Third, with asymmetric demands, the welfare gains of introducing differentiated tolling rise strongly for the country with lower local demand.

\subsubsection{Strategic competition on serial networks}

Making abstraction of externality issues, the serial tax competition problem bears some analogies to the problem of vertical integration in the literature on industrial organisation (see, e.g., Tirole (1988)). When there is monopolistic behaviour both on the output market and on the market for intermediate inputs, every producer applies his optimal profit margin without taking into account that he decreases the profit base of the other producers in the supply chain. The result is 'double marginalisation': overall mark-ups are higher but total profits lower than in the case with full vertical integration. As Tirole (1988) puts it: "What is worse than a monopoly? A chain of monopolies”. Not surprisingly, the small literature dealing with serial links operated by different private firms has confirmed this phenomenon. Overall payments by road users are therefore too high ${ }^{10}$.

The most relevant strategic interactions occur when different governments are responsible for price and capacity decisions on different links of a serial network. Levinson (2000) assumes fixed capacity and focuses on the choice of revenue raising mechanisms (fuel tax versus toll) in the absence of congestion and other external costs. He finds that larger regions are more likely to tax than smaller regions, who are relatively better off with (cordon) tolls at their borders. In a related paper, Levinson (2001) analyses US states' choice of instruments for financing transportation infrastructure. He argues that states will engage in a 'beggar-thy-neighbor' strategy in which one state will retaliate by tolling in response to another state's decision to toll. This was found to occur more when the two states had a large number of commuters driving between the two states. The econometric analysis confirms the theoretical prediction of tax exporting behavior: jurisdictions are more likely to prefer tollfinancing (instead of, e.g., using fuel taxes) when the share of non-residential users is

\footnotetext{
${ }^{10}$ In the transport sector, many studies dealing with private operators of serial links are applied to the airline industry. For example, Pels and Verhoef (2004) and Brueckner (2005) both considered multiple airports in series. Passengers travel from one airport to another (and back) so that the airports produce complements.
} 
large. Tax exporting behavior is also confirmed by Rork (2009) in an empirical exercise that captures the interaction between states in a dynamic way, looking at the fluctuation of toll revenues over time using spatial econometric techniques. Finally, Rietveld and van Woudenberg (2005) use cross-section data to explain fuel price differences between countries in Europe. Horizontal gasoline tax competition is used more intensively by smaller countries (Luxemburg), in line with the theory proposed by Kanbur and Keen (1993). There is no sign that negative pollution externalities lead to higher taxes ${ }^{11}$.

Much of the above analysis focuses on tolling decisions only. De Borger, Dunkerley, Proost (2007) study pricing and investment decisions on a congested twolink transport corridor where each link is controlled by a different government. In a two-stage non-cooperative game both governments strategically set capacity in the first stage and play a pricing game in the second stage ${ }^{12}$. The model confirms the phenomenon of double marginalization also for public operators: transit tolls on the network will be inefficiently high. Each operator prices above the marginal external cost in order to extract revenues from transit, disregarding the revenue losses imposed on other operators. If for some reason through traffic cannot be taxed, then the Nash equilibrium tolls are inefficiently low. The low toll again implies many local travelers and increasing congestion levels, discouraging transit. Regional toll levels on through traffic are found to be strategic substitutes, but capacities are strategic complements. Hence, raising the toll on transit through a given country by one euro raises the toll on the whole trajectory by less than a euro, because the other country reduces its toll level. However, when one country on the corridor increases transport capacity, it forces the other country to do the same. The intuition goes as follows: when one region increases capacity, it reduces the total generalized cost of transit. This attracts more transit traffic that will also use the capacity in the other region; increasing congestion levels in the other region "force" the other region to also extend its

\footnotetext{
${ }^{11}$ Of course, tax exporting is also found in numerical optimization models that implicitly or explicitly assume simple transport networks. For example, De Borger, Courcelle and Swysen (2004) study tax policies by individual regions in a large-scale numerical optimization model with both domestic and international freight transport. They illustrate the extent to which optimal tax rates rise when transit shares increase. The welfare losses from strategic pricing by individual regions were found to be relatively small.

${ }^{12}$ A related but slightly different problem is studied by Bassanini and Pouyet (2005). They focus on the non-cooperative choice of financing system rather than pricing levels, (that is, does the system allow subsidies to be paid out of general tax revenues) by two national infrastructure managers who maximize welfare in their country while covering network costs.
} 
capacity. Finally, capacity strongly affects tolling: higher capacity investment in a given region reduces optimal tolls in this region under all pricing regimes.

Importantly, strategic behavior by regions now has quite dramatic welfare effects. If transit is sufficiently important, it may be welfare improving for a higherlevel authority such as the EU or the US not to allow individual regions to introduce any tolling at all. The reason is that the potential to toll transit would lead to insufficient investment and strong tax exporting behavior, so that welfare is actually higher in the absence of any tolling at all.

Previous line of research on serial transport corridors has been extended along several lines. For example, Mun and Ahn (2008) focus on pricing on serial roads, ignoring capacity decisions. They distinguish between the case with and without congestion, and consider a large set of possible ownership structures ${ }^{13}$. Perhaps unsurprisingly, they show that the ranking of the different regimes may differ depending on whether or not there is heavy congestion. Ubbels and Verhoef (2008) study policy interactions between an urban and a regional government, both controlling one link of a two-link serial road network; governments only care for the welfare of their own inhabitants. Regional drivers use both roads (commuters to the city, for example), whereas urban drivers use the urban road only. Governments set capacity and toll on one link, in a two-stage game where first capacities are decided and next tolls are decided upon. The authors consider both Nash and Stackelberg games; in the latter case, the region and the city can each act as leader. Although the hinterland region has the same instruments as the city, the model shows substantial tax exporting possibilities for the city (because commuters use the city road but not vice versa) with substantial aggregate welfare losses. It is the fact that governments compete that matters, not so much whether they make simultaneous (Nash) or sequential (Stackelberg) decisions. In the latter case, who is the leader does not seem to matter much for welfare either.

The idea of a simple serial network is obviously not limited to the case of sequential links on a road or rail network. It is also well suited if one is interested in studying the interaction between airports and the carriers that serve them, or between

\footnotetext{
${ }^{13}$ These include a situation where one road is privately operated whereas the other is publicly controlled, the case of one toll-free and one privately operated road, and the case of one toll-free and one public road.
} 
ports and other components in a logistic chain (for example, the port's hinterland). Several studies have investigated such issues in detail.

For example, Yuen, Basso and Zhang (2008) focus on the interaction between a port or airport gateway and a road, controlled by different authorities. Moreover, the gateway is served by oligopolistic carriers that carry both "local" (destination is the gateway region) and "transit" (destination is the hinterland region) traffic. The hinterland road has its own local users (e.g., local commuters). The model compares the case in which the gateway implements congestion pricing with the no-congestionpricing base case (here the gateway's charge is just equal to its operating cost). It is shown that, if the gateway maximizes joint profit (of the gateway plus the carriers), congestion pricing will increase gateway charges. The hinterland authority will reduce its (optimal) road tolls independently of whether or not it is able to price-discriminate between the local and transit cargo traffic. Moreover, a move by the gateway towards congestion pricing negatively affects hinterland welfare so that, if the gateway and the road were to belong to the same jurisdiction, this effect would be taken into account in setting optimal gateway congestion prices.

De Borger and De Bruyne (2011) study the implications of vertical integration in the shipping and logistics industry. In the initial situation, a number of competing private terminal operators are active at the port level, and private profit maximizing trucking firms are responsible for shipping goods over the port's hinterland to their end destination. Moreover, port-related traffic interacts with local traffic on the hinterland road network. A welfare-maximizing government uses two policy instruments, a port access fee and a hinterland road toll. The model shows that, first, vertical integration in the logistic chain implies higher optimal port access charges. The intuition is that the optimal port fee corrects for inefficient pricing behaviour in the logistics industry, and vertical integration eliminates double marginalization by terminal operators and transport firms. Second, both under separation and integration, optimal port fees may imply subsidies if downstream firms enjoy a high degree of market power. Third, the government not only has an incentive to promote competition between downstream firms (because it leads to lower prices), but under 
specific conditions it may be beneficial to approve of vertical mergers in the logistic chain $^{14}$.

Finally, Benoot, Brueckner and Proost (2012) use the De Borger, Dunkerley, Proost (2007) framework to study the regulation of intercontinental flights via the charges and capacity choice in intercontinental airports. Two continents (for example, the US and the EU, or the US and China) control each either the departure or landing airports of intercontinental flights; they each decide on the airport charge and capacity. The paper shows that the welfare losses of intercontinental airport competition can be more important than the welfare losses of imperfect airline competition. Another result is that the additional charges (for example on immigration in the US, EU carbon permits) imposed on intercontinental flights are to a large extent paid by the continent imposing them.

Two remarks conclude this subsection. First, the specific issue of strategic behavior in building cross-border infrastructure has also received quite some attention in the international economics literature. Björner (1996) developed a simple two product-two country general equilibrium model in which the production of one good uses two inputs, viz., labour and freight transport on both the domestic and foreign transport network. Using this framework, he was probably the first to explicitly illustrate tax exporting behaviour in a model incorporating transport decisions. More recently, Bond (2006) investigates the consequences of independent decision making by governments and examined the effects of trade liberalization on the incentive to invest in cross-border infrastructure. Furthermore, Mun and Nakagawa $(2008,2010)$ develop trade models with cross-border infrastructure. They show that an investment in cross-border infrastructure by one country decreases the transport costs of both import and export goods, benefiting both the home country and the neighboring country. In the absence of pricing, this expenditure externality implies that independent decision making leads to under-investment in infrastructure; this result need not hold when pricing of capacity is introduced ${ }^{15}$. Among other results, the analysis finds that each government levies an excessively high price for infrastructure use, confirming earlier results (De Borger, Dunkerley and Proost (2007)).

\footnotetext{
${ }^{14}$ For a recent extension, also see Cantos-Sanchez, Moner-Colonques, Sempere-Monerris and AlvarezSanJaime (2010).

${ }^{15}$ Competition between governments leads to an obvious trade-off: investment in capacity lowers the transport cost and thereby increases the gains from trade, but it increases the fiscal burden; raising user charges increases revenues, but it decreases the gains from trade.
} 
Second, the literature has so far studied toll and capacity outcomes under the assumption of competing governments. In some cases, however, this may not be very realistic. For example, when only a few regions are involved, they can easily avoid competition through direct negotiations. Given the direct impact of toll and capacity decisions in a region on the travel demand by consumers and firms from adjacent regions, assuming bargaining between the different governments over tolling and (especially cross-border) capacity expansions seems to be at least equally plausible as assuming competition. It is surprising, therefore, that negotiated toll and capacity decisions have not yet received more attention in the literature. One recent paper taking this approach is De Borger and Pauwels (2010). They consider a similar setting as Ubbels and Verhoef (2008), but assume partial cooperation between the regions, modeled as a Nash bargaining problem with endogenous disagreement points. Regions use capacity to affect their bargaining position at the tolling stage. It is shown that this leads to lower tolls and higher quality and capacity investment than fully non-cooperative behavior. Strategic behavior at the investment stage does induce regions to offer lower quality and invest less in capacity as compared to full cooperation. Most importantly, the analysis suggests that Nash bargaining to a large extent resolves the problem of large welfare losses due to toll and capacity competition on serial networks, previously pointed out in the literature. Further research has to confirm this conclusion but it seems, at least in a serial setting, that bargaining leads to substantially different outcomes than competition, with much less undesirable welfare implications.

There is another reason why the assumption of strictly competing governments may not hold. In some cases, regions that suffer most from high tolls elsewhere can call upon a federal authority to block too high charges by other regions. This potential use of veto power is considered in a recent paper by Westin, Franklin, GrahnVoorneveld and Proost (forthcoming). They study the situation where a city suffers from a lot of transit traffic originating from one neighboring region. The city can decide to toll the city road but also to build a tolled ring road. The city will obviously exploit its monopoly position and implement too high charges on the city road, and it will only build the bypass if this increases its revenues. The neighboring city can lobby at the federal level to obtain a veto right for all charges and investments that affect their welfare. This veto power is important, because it changes the threat point 
and the bargaining power of the two regions. Veto rights may give rise to more efficient tolls and a different welfare distribution.

\subsubsection{Comparing parallel and serial networks}

To understand the role of the network structure for the implications of strategic behavior, a few studies explicitly compare outcomes for different network structures. Two clear results have emerged from these analyses. First, focusing on private operators, Small and Verhoef (2007) show that an increasing number of parallel private operators (suppliers of substitutes) yields tolls that are closer to the first-best level, while the opposite holds for an increasing number of serial competitors (suppliers of complements) ${ }^{16}$. Second, a formal comparison of simple serial and parallel networks -- where individual links of the network are operated by different governments - is provided in De Borger, Dunkerley and Proost (2008)). They find that reaction functions for transit tolls are much more responsive to tolls in other jurisdictions on serial networks than on parallel ones. The policy implication of this finding is that, ceteris paribus, one expects much more tax exporting behavior (hence, higher toll levels) in serial transport corridors than on competing parallel road networks. Moreover, the inability to toll transit has quite dramatic negative welfare effects on parallel networks, partly because it strongly reduces the incentives to invest. On the contrary, in serial transport corridors it may actually be undesirable to toll transit. Again, this has a clear policy implication. It implies that it may not be wise for the EU to allow individual countries to independently decide on toll levels on transit traffic that passes through their jurisdiction.

\footnotetext{
16 They speculate that, to the extent that public operators would be engaged in tax exporting (raising toll revenues from foreign users), the same is likely to hold for government operators.
} 
Table 3: Horizontal competition with multiple operators in parallel and serial networks

\begin{tabular}{|c|c|c|c|c|c|}
\hline Authors & $\begin{array}{l}\text { Type of } \\
\text { Network } \\
\text { (P: parallel, } \\
\text { S:Serial, } \\
\text { M: mixed) }\end{array}$ & $\begin{array}{l}\text { Market } \\
\text { structure } \\
\text { (M: } \\
\text { monopoly, } \\
\text { D: duopoly, } \\
\text { O: } \\
\text { oligopoly) }\end{array}$ & $\begin{array}{l}\text { Control } \\
\text { over } \\
\text { instruments } \\
\text { (P: private, } \\
\text { G: public, } \\
\text { F: free) }\end{array}$ & $\begin{array}{l}\text { Instruments } \\
\text { used (P: } \\
\text { pricing, C: } \\
\text { capacity) }\end{array}$ & Comments \\
\hline $\begin{array}{l}\text { De Palma and Lindsey } \\
(2000)\end{array}$ & $\mathrm{P}$ & $\mathrm{D}$ & GPF & $\mathrm{P}$ & \\
\hline Van Dender (2005) & $\mathrm{P}$ & $\mathrm{D}$ & $\mathrm{P}$ & $\mathrm{P}$ & \\
\hline $\begin{array}{l}\text { De Borger, Proost and } \\
\text { Van Dender (2005) }\end{array}$ & $\mathrm{P}$ & $\mathrm{D}$ & $\mathrm{G}$ & $\mathrm{P}$ & Local and through traffic \\
\hline Bjorner (1996) & $\mathrm{S}$ & $\mathrm{D}$ & $\mathrm{G}$ & $\mathrm{P}$ & $\begin{array}{l}\text { Local and through traffic. } \\
\text { Focus on } \\
\text { freight/international trade }\end{array}$ \\
\hline $\begin{array}{l}\text { De Borger, Courcelle } \\
\text { and Swysen (2004) }\end{array}$ & $\begin{array}{l}\text { No specific } \\
\text { network }\end{array}$ & M & $\mathrm{G}$ & $\mathrm{P}$ & $\begin{array}{l}\text { Large scale numerical } \\
\text { simulation model }\end{array}$ \\
\hline Levinson (2000) & $\mathrm{S}$ & $\mathrm{M}$ & $\mathrm{G}$ & $\mathrm{P}$ & Local and through traffic \\
\hline Levinson (2001) & $\mathrm{S}$ & $\mathrm{M}$ & $\mathrm{G}$ & $\mathrm{P}$ & Local and through traffic \\
\hline $\begin{array}{l}\text { De Borger, Dunkerley } \\
\text { and Proost (2007) }\end{array}$ & $\mathrm{S}$ & $\mathrm{D}$ & $\mathrm{G}$ & $\mathrm{PC}$ & $\begin{array}{l}\text { Two stage price-capacity } \\
\text { competition, local and } \\
\text { through traffic }\end{array}$ \\
\hline Mun and Ahn (2008) & $\mathrm{S}$ & $\mathrm{D}$ & GPF & $\mathrm{P}$ & \\
\hline $\begin{array}{l}\text { Mun and Nakagawa } \\
(2008)\end{array}$ & $\mathrm{S}$ & $\mathrm{D}$ & $\mathrm{G}$ & $\mathrm{C}$ & $\begin{array}{lr}\text { Cross } & \text { border } \\
\text { infrastructure, } & \text { no } \\
\text { congestion } & \\
\end{array}$ \\
\hline $\begin{array}{l}\text { Mun and Nakagawa } \\
(2010)\end{array}$ & $\mathrm{S}$ & $\mathrm{D}$ & GPF & $\mathrm{PC}$ & $\begin{array}{lr}\text { Cross } & \text { border } \\
\text { infrastructure, } & \text { no } \\
\text { congestion } & \\
\end{array}$ \\
\hline $\begin{array}{l}\text { Rietveld and van } \\
\text { Woudenberg (2005) }\end{array}$ & $\begin{array}{l}\text { No specific } \\
\text { network }\end{array}$ & $\begin{array}{l}\text { No explicit } \\
\text { market } \\
\text { structure }\end{array}$ & G & $\begin{array}{l}\mathrm{P} \\
\text { taxes })\end{array}$ & $\begin{array}{l}\text { Empirical analysis of fuel } \\
\text { tax competition }\end{array}$ \\
\hline $\begin{array}{l}\text { De Borger, Dunkerley } \\
\text { and Proost (2008) }\end{array}$ & PS & $\mathrm{D}$ & $\mathrm{G}$ & $\mathrm{PC}$ & $\begin{array}{l}\text { Comparison multiple } \\
\text { public operators in parallel } \\
\text { and serial settings }\end{array}$ \\
\hline $\begin{array}{l}\text { Yuen, Basso and Zhang } \\
(2008)\end{array}$ & $\mathrm{S}$ & $\mathrm{MO}$ & PG & $\mathrm{P}$ & $\begin{array}{l}\text { One port, oligopoly } \\
\text { carriers }\end{array}$ \\
\hline $\begin{array}{l}\text { Ubbels and Verhoef } \\
(2008)\end{array}$ & $\mathrm{S}$ & $\mathrm{D}$ & $\mathrm{G}$ & $\mathrm{PC}$ & $\begin{array}{l}\text { Two stage price-capacity } \\
\text { competition; local users on } \\
\text { urban road, regional users } \\
\text { on urban and regional road }\end{array}$ \\
\hline $\begin{array}{l}\text { De Borger and Pauwels } \\
(2010)\end{array}$ & $\mathrm{S}$ & $\mathrm{D}$ & $\mathrm{G}$ & $\mathrm{PC}$ & $\begin{array}{ll}\begin{array}{l}\text { Allows for } \\
\text { cooperation } \\
\text { bargaining }\end{array} & \begin{array}{r}\text { partial } \\
\text { through }\end{array} \\
\end{array}$ \\
\hline $\begin{array}{l}\text { De Borger and De } \\
\text { Bruyne }(2011)\end{array}$ & $\mathrm{S}$ & $\mathrm{MO}$ & PG & $\mathrm{P}$ & $\begin{array}{l}\text { One port, oligopolistic } \\
\text { carriers; focus on vertical } \\
\text { integration between port } \\
\text { and logistics }\end{array}$ \\
\hline $\begin{array}{l}\text { Benoot, Brueckner and } \\
\text { Proost }(2012)\end{array}$ & $\mathrm{S}$ & $\mathrm{D}$ & $\mathrm{PG}$ & $\mathrm{PC}$ & $\begin{array}{l}\text { Pricing of intercontinental } \\
\text { flights }\end{array}$ \\
\hline $\begin{array}{l}\text { Westin, Franklin, } \\
\text { Grahn-Voorneveld and } \\
\text { Proost (forthcoming) }\end{array}$ & $\mathrm{S}$ & DO & $\mathrm{G}$ & $\mathrm{PC}$ & $\begin{array}{l}\text { Bargaining setting, } \\
\text { potential veto rights }\end{array}$ \\
\hline
\end{tabular}




\subsection{Competition between logistic chains}

In this section, we focus on models that have studied (parallel) competition between (serial) logistic chains that are not necessarily integrated ${ }^{17}$. This often makes sense; for example, airports often compete with other airports (for example, consider airports in the San Fransisco area, or competition between Brussels and Amsterdam), but to some extent they are each served by the same airlines. Similarly, ports (for example, Hamburg-Le Havre range, Californian ports) compete with others; goods are transported by trucking firms or railroad operators to their final destination using the port's hinterland. We summarize the few existing studies in Table 4.

As a prelude to such models, Basso and Zhang (2007) reconsidered pricing and capacity decisions by private competing facilities (port, airport). Each facility is modeled as an upstream firm that provides services to downstream firms (e.g., carriers, trucking firms). The latter deliver goods to final consumers; they are allowed to have market power in the output market. The paper analyzes both single stage and two-stage Nash competition in prices and capacities, and compares duopoly outcomes with monopoly and the first-best. It confirms several findings of the earlier literature. For example, duopoly facilities have lower prices than a monopolist and that they offer lower service quality if the facilities first decide on capacities and then on prices. However, the latter result disappears when capacity and price decisions are made simultaneously; duopoly and monopoly now provide the same service quality ${ }^{18}$. The analysis further shows that, if the downstream market is imperfectly competitive, capacity rules imply that a monopoly facility provides a higher service level than the central planner.

A number of papers have used a similar but slightly different vertical structure to analyze the specific question how governments should deal with the problem of port (or airport) and hinterland congestion. For example, Yuen and Zhang (2007) assume oligopolistic ports that compete in prices, and they analyze welfare-

\footnotetext{
${ }^{17}$ Acemoglu and Ozdazgar $(2007,2008)$ recently provide a detailed theoretical pricing analysis of competition and efficiency on general network markets. Among other things, they show that more competition among oligopolists can reduce efficiency on congested markets, and that pure strategy equilibria may not exist, especially when congestion functions are highly nonlinear.

${ }^{18}$ This difference in results of course raises the question which decision structure is most realistic, sequential or simultaneous decisions? There seems to be a tendency in the literature that sequential decisions are more realistic because capacity decisions and execution of capacity adjustments take more time than the process of deciding and implementing price changes.
} 
optimal port access charges and hinterland congestion tolls, assuming that port charges and hinterland road tolls are controlled by a different regional government. Capacities are fixed. They show, among others, that profit-maximizing ports internalize hinterland congestion in as far as it affects their own, but not their competitor's, customers. More recently, De Borger, Proost and Van Dender (2008) assume two private ports compete for the same overseas customers and each has a downstream, congestible transport network to a common hinterland. The local (country) governments care about local welfare only and decide on the capacities of the port and of the hinterland network. Compared to Yuen and Zhang, the model has an exogenous hinterland congestion toll, but capacity decisions in port and hinterland capacity are included. It is shown that government investment in a port's capacity reduces prices and congestion at both ports, but it increases hinterland congestion in the region where the port investment is made. Investment in a port's hinterland is likely to lead to more port congestion and higher prices for port use, and to less congestion and a lower price at the competing port. Not surprisingly, the induced increase in hinterland congestion is a substantial cost of port investment that strongly reduces the direct benefits of extra port activities.

Also, Wan and Zhang (2012) study two competing chains, each consisting of a seaport and its urban roads which connect the port to the (common) inland market. The urban roads are congestible; they are shared by port-related trucks and local commuters having different time values. Ports are private, but the hinterland is controlled by government. In this setting, the model focuses on hinterland tolls and capacity; port congestion and capacity is ignored. Both price and quantity competition is treated, and the analysis considers both uniform and discriminatory pricing of trucks and cars. With quantity competition, it is found that an increase in road capacity for a given logistic chain will improve the corresponding port's profit, while reducing profit for the rival's port; road congestion of both chains will fall as a result. Remark that, with uniform tolls roads are taxed above marginal external congestion cost, provided that the value-of-time of shippers is sufficiently large relative to that of commuters. When a discriminative toll system is implemented, however, commuters are tolled at the marginal congestion costs while truck tolls are much lower. 
Table 4: Competition between logistic chains

\begin{tabular}{|c|c|c|c|c|c|}
\hline Authors & $\begin{array}{l}\text { Market } \\
\text { structure } \\
\text { (D: } \\
\text { duopoly) }\end{array}$ & $\begin{array}{l}\text { Control } \\
\text { over } \\
\text { instruments } \\
\text { (P: private, } \\
\text { G: public) }\end{array}$ & $\begin{array}{l}\text { Instruments } \\
\text { used (P: } \\
\text { pricing, C: } \\
\text { capacity) }\end{array}$ & $\begin{array}{l}\text { Specific } \\
\text { transport } \\
\text { application }\end{array}$ & Comments \\
\hline $\begin{array}{l}\text { Basso and } \\
\text { Zhang } \\
(2007)\end{array}$ & $\mathrm{D}$ & $\mathrm{P}$ & $\mathrm{PC}$ & $\begin{array}{lr}\text { Two ports } & \text { or } \\
\text { airports } & \\
\text { provide } & \\
\text { services } & \text { to } \\
\text { carriers that } \\
\text { deliver } \\
\text { consumers }\end{array}$ & $\begin{array}{l}\text { Single and two } \\
\text { stage games, } \\
\text { imperfect } \\
\text { competition } \\
\text { carrier market }\end{array}$ \\
\hline $\begin{array}{l}\text { Yuen and } \\
\text { Zhang } \\
(2007)\end{array}$ & $\mathrm{D}$ & $\mathrm{G}$ & $\mathrm{P}$ & $\begin{array}{l}\text { Ports and } \\
\text { hinterland } \\
\text { controlled by } \\
\text { different } \\
\text { governments }\end{array}$ & $\begin{array}{l}\text { Focus on port and } \\
\text { hinterland charges }\end{array}$ \\
\hline $\begin{array}{l}\text { De Borger, } \\
\text { Proost and } \\
\text { Van Dender } \\
(2008)\end{array}$ & D & GP & PC & $\begin{array}{l}\text { Ports and } \\
\text { hinterland } \\
\text { controlled by } \\
\text { different } \\
\text { governments }\end{array}$ & $\begin{array}{l}\text { Focus on port } \\
\text { charges and port } \\
\text { and hinterland } \\
\text { capacity }\end{array}$ \\
\hline $\begin{array}{l}\text { Wan and } \\
\text { Zhang } \\
(2012)\end{array}$ & D & $\mathrm{G}$ & $\mathrm{PC}$ & $\begin{array}{lr}\begin{array}{l}\text { Ports } \\
\text { airports and } \\
\text { their }\end{array} \\
\text { hinterlands }\end{array}$ & 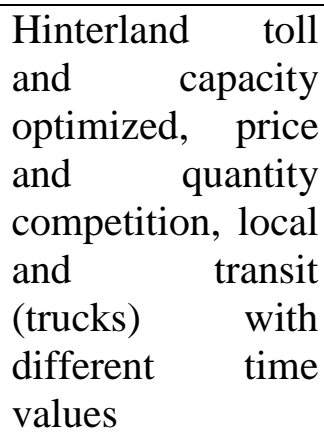 \\
\hline
\end{tabular}




\section{$\underline{5 .}$ Vertical competition between governments}

Despite its relevance for the transport sector, the insights of the public finance literature on vertical tax competition (see Section 3) have hardly been translated or applied to transport taxation and pricing. That the issue is important is clear. Most transport flows are not only taxed or subsidised in various different ways, but typically the different taxes are set by different hierarchical levels of government ${ }^{19}$. For example, people that both use their private car and public transport face payments of registration taxes on their cars, they pay fuel taxes, they pay for parking, they pay public transport fares, they may face road tolls, etc. Some of the taxes may be set by higher level governments (e.g., in most countries fuel taxes are determined at the national level), but public transport fares, road tolls and parking charges may be set by local authorities. Moreover, in some cases clear rules exist for the sharing of the revenues generated out of the various taxes. Figure 2 presents the general structure of vertical tax competition between government levels.

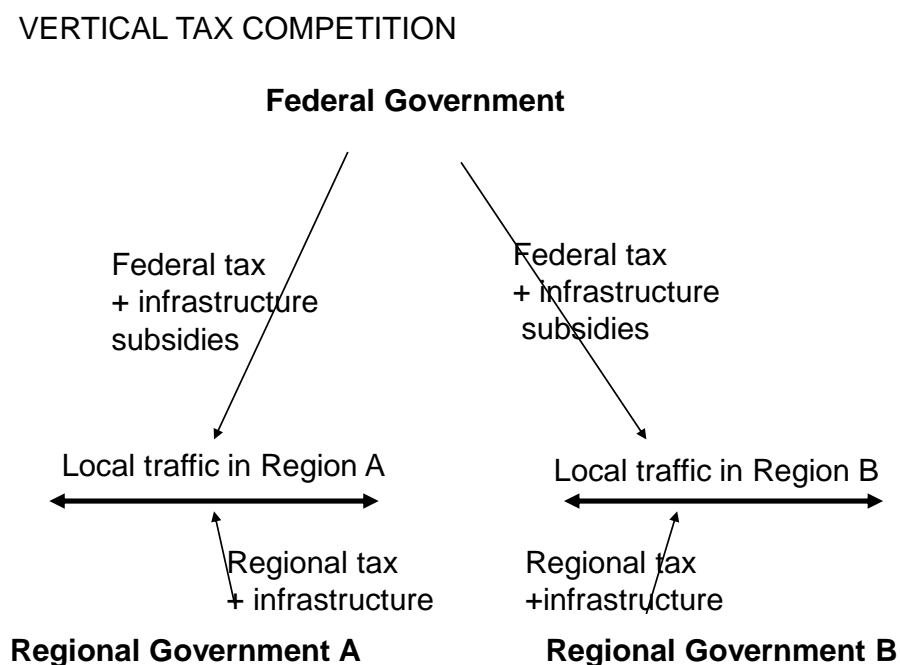

\footnotetext{
${ }^{19}$ Although we focus on price competition in this section, the interaction between different hierarchical governments is not limited to pricing. For example, in the US a classic case of interaction between federal and state policies is the effect of federal environmental legislation (CAFE) on individual states' fuel tax revenues. The same interaction exists between the EU fuel efficiency regulation and local fuel taxes.
} 
Figure 2. Vertical competition between government levels

In the remainder of this section, we review the scarce transport literature on vertical tax and expenditure competition. We first discuss the division of authority between different government levels in setting taxes and charges on transport services. Then we turn to the allocation of investment decisions over government levels.

\subsection{Vertical tax competition}

The literature provides a few studies that deal with two specific applications of vertical tax interaction. First, Besley and Rosen (1998) and Devereux, Lockwood and Redoano (2007) look at the effect of US federal taxes on state gasoline taxes. They find rather weak evidence of vertical tax interaction between the two government levels; similarly, there is no strong evidence of horizontal tax competition. Second, De Borger et al. (1998) and Proost and Sen (2006) contain very preliminary illustrative analyses of the problems implied by urban-federal government policies. The former paper illustrates different pricing optima for a city government (Brussels) and a regional government within a country (Belgium), and it considers simple forms of revenue-sharing, but it does not formally analyse the optimal policies that correct the vertical inefficiencies. The latter study theoretically illustrates the optimal tax problem when a local and a national government are involved in a Stackelberg game, and it empirically verifies some of the theoretical predictions.

Given the lack of additional literature, in what follows we limit the discussion to an intuitive explanation of the nature and the importance of the problem. We consider a highly specific context where an urban or regional government and a federal government use different policy instruments to control the transport sector. The specifics of the situation are described in Table 5. The idea is that the city or regional government uses 'local' instruments such as congestion tolls or parking fees, whereas the federal level also controls instruments such as the fuel tax. This setting allows us to identify at least four reasons why the tax structure and the level of taxation will be suboptimal:

(i) There are fiscal externalities associated with overlapping tax bases. An increase in federal fuel taxes reduces transport demand, and it therefore affects 
revenues of local congestion tolls and public transport fares for the regional or city government. This may be ignored by the national government in setting fuel taxes, yielding too high federal taxes.

(ii) Tax exporting by the city government. For example, if it cares less about commuters into the city than about its own residents, local congestion charges on commuters will be excessively high from an overall welfare viewpoint.

(iii) There are externality spill-overs. The local authorities only care about externalities imposed on local residents; this induces them to set local taxes too low.

(iv) The use of imperfect and different instruments by the different governments.

Table 5: Regional and global optima with vertical interaction

\begin{tabular}{|l|l|l|}
\hline & $\begin{array}{l}\text { Regional or city } \\
\text { government }\end{array}$ & Federal government \\
\hline Externality spill-over & $\begin{array}{l}\text { Cares about externalities } \\
\text { imposed on city's or } \\
\text { region's residents only; } \\
\text { e.g. it ignores time losses } \\
\text { for commuters }\end{array}$ & $\begin{array}{l}\text { Cares about externalities } \\
\text { imposed on all national } \\
\text { residents; e.g. internalise } \\
\text { commuting time losses }\end{array}$ \\
\hline Tax exporting & $\begin{array}{l}\text { Yes; export taxes to non- } \\
\text { residents }\end{array}$ & No \\
\hline Overlapping tax bases & Yes, partially & Yes, partially \\
\hline instruments in tax & $\begin{array}{l}\text { Use of local congestion } \\
\text { taxes, local public } \\
\text { transport prices, parking } \\
\text { fees... }\end{array}$ & $\begin{array}{l}\text { Use of all instruments, } \\
\text { including fuel taxes }\end{array}$ \\
\hline Tax revenue & $\begin{array}{l}\text { Local congestion taxes, } \\
\text { local public transport } \\
\text { surplus or deficit, parking } \\
\text { fees }\end{array}$ & $\begin{array}{l}\text { Fuel taxes, all federal } \\
\text { congestion taxes, all non- } \\
\text { local public transport net } \\
\text { revenues }\end{array}$ \\
\hline Shadow cost of funds & Regional & Federal \\
\hline
\end{tabular}

The interaction of all the above implications of vertical tax competition leads to results that are difficult to fully predict a priori. This is illustrated in the only available transport study dealing explicitly with this topic. Proost and Sen (2006) use a similar but highly simplified setting than the one documented in Table 5. They assume there is an urban and an (overlapping) regional government, where each government only has one instrument available. The city controls local parking fees, 
whereas the regional government decides on a peak period cordon toll around the whole area to control congestion. The cordon toll is paid only by commuters, not by local city residents. The analysis assumes that the behaviour of each government level consists of maximising the welfare of the representative citizen in its constituency: the urban government maximises the welfare of its inhabitants only, whereas the regional government maximises the sum of the welfare of all citizens (i.e., its urban citizens and its commuters, where the weights correspond to their relative importance in the population).

Despite the extremely simple setting used for this example, there are some useful lessons to be learned:

1. Even if each government maximises the welfare of all its voters, this generates inefficiencies because of overlapping tax bases and a tendency for tax exporting by the core urban area.

2. Non-cooperative equilibria do not necessarily perform very poorly in welfare terms as long as each government cares about externalities. In a sense, correcting externalities is more important than the side effects of tax competition.

3. Changing the sharing rules for tax revenue can decrease the welfare loss of noncooperative equilibria.

Federal government intervention in transport pricing by regions can also be studied as an asymmetric information problem where the regions have better information on local road conditions and externalities (congestion, air pollution, etc.) than the federal government. Van der Loo and Proost (2011) study this problem and find that the federal government can, for air pollution types of externalities, construct incentive schemes to make the regional government transmit the correct information and implement optimal external cost pricing. This is more difficult in the case of congestion externalities because the incentive compatibility conditions are violated; the main reason is that congestion affects the level of demand and local profits (for details, see Van der Loo and Proost (2011)).

\subsection{Who should decide on local transport investments?}

One of the important questions in federal states is the allocation of transport infrastructure investments. In many countries, transport infrastructure is paid to a 
large extent by federal funds under the form of dedicated grants. This raises two questions. First, what is the rationale for this federal intervention? Second, how efficient is this practice of federal financing?

In the normative theory of fiscal federalism (see section 2.1), there are two motivations for federal grants. The first is insufficient fiscal capacity at the lower level. The second one is the existence of benefit spill-overs to neighbouring jurisdictions. Insufficient fiscal capacity can best be solved by unconditional grants or tax revenue sharing, as there is no reason for federal intervention in the allocation of local public goods. Benefit spill-overs may be a better justification for federal grants. They can correct the effects of the spill-overs and provide appropriate incentives to local governments to make the correct investment decisions.

In reality, however, once we take account of the political decision-making process, there are many doubts about the efficiency of federal transport infrastructure expenditures. For example, in the US, the Federal Highway Trust Fund (FHTF) was set up to finance the National System of Interstate Highways (Proost et al. (2010)). The Fund is mainly financed by dedicated taxes on motor fuel, collected by a federal agency. The federal matching grants for individual projects, on average $80 \%$ of the total costs, are based on technical criteria of the projects. Though Congress does not decide on the project selection of the FHTF funds, members of Congress have developed a practice of requiring an increasing number of "earmarks" or "demonstration projects", i.e. additional projects from other federal funds that the representatives require as a condition for their approving vote for the legislation package.

The same pork barrel mechanism is probably at work in the allocation of EU infrastructure funds. One of the driving forces in the federal allocation of local expenditures is again the sharing of the costs for local supply over all regions. This is an incentive for strategic delegation of regional representatives to the federal level; regions with a high preference for the local public good hope that their representative will successfully bargain for a high share for the region. As shown by Besley and Coate (2003), this implies inefficiencies. To illustrate this, Proost et al. (2010) found that more than half of the projects on the TEN priority list do not pass the Cost Benefit hurdle; in addition, many projects have almost no spill-overs to other EU countries. Recently, De Rus and Socorro (2011) as well as Proost et al.(2011) discuss some proposals for designing better rules for European federal investment aid. 


\section{Political economy models of transport decisions}

A political economy approach to transport decision making may shed light on a number of observed outcomes of the political process (see, for example, the discussion in Section 5.2 above). The first models looking at the political economy of transport decision-making are available in the literature. However, the majority of these studies focuses on the political economy of introducing road pricing or tolling in a setting with a single government (Marcucci, Marini and Ticchi (2006), King, Manville and Shoup (2007), De Borger and Proost (2012)). The literature that considers the politics of transport decisions in a multi-government world is still very much underdeveloped.

This being said, the first theoretical and empirical studies dealing with these issues have appeared in the literature. For example, Knight (2004) uses the legislative bargaining framework as one of the ingredients of the political mechanism to explain the allocation of highway funds in the US. Starting from the observation that the assumption that federal supply of public goods is uniform over regions is empirically invalid, he shows that political power can be used at the federal level to favor certain regions. This inefficiency is highly costly: he found that for every two dollar spent, one dollar was wasted. Rosenbloom and Wachs (2012) have therefore proposed alternative financing schemes in which the role of apparently highly inefficient federal funding is strongly reduced.

The inefficiencies in the allocation of investment funds for the TEN-T's in Europe described in Section 5.2 probably also relate to the details of the political mechanism at work. Proost and Zaporozhets (2010) use a model where the composition of the regions is homogenous and where the regional investments have to observe a federal fixed sharing rule. They find that political bargaining produces an allocation of investment funds that is, surprisingly, rather efficient. When regions are not homogenous, the Besley and Coate (2005) model offers an explanation. In this model, those people that like particular types of local transport infrastructure may prefer to bring the decisions to the federal level rather than having decisions at the regional or local level. This will happen if they know or expect that it will be easier to 
get a majority at the federal than at the local level. This behaviour may imply the inefficiencies observed in the available empirical work.

Note that the legislative bargaining framework used by, e.g., Knight (2004), assumes that, once parliament has taken its decisions, there is perfect control of politicians and the executing agencies. Glazer and Proost (2010) recently relaxed these assumptions, allowing for insufficient control of politicians and agencies by voters, and taking into account the behaviour of the executive agency. Using a median voter model combined with rent seeking by the allocating agency, they explain why one observes universal service for many local public goods (say, public transport) that are financed by federal funds. Universal service saves the 'median voter region' the rent seeking efforts that it needs to make to obtain service in its own region when the median district would decide that only $l$ regions $(l<n)$ would get the service. This problem of incomplete control of politicians and agencies may be partially overcome by decentralising decisions on local public goods to the regional level. In this case, local voters can rely on yardstick competition (comparing efficiency of agencies and politicians across regions) to limit the power of inefficient politicians or agencies; in this sense, regional decision-making improves the accountability of government.

Finally, a recent study of Russo (2012) allows for multiple governments when studying political decisions on transport pricing. His results confirm that a political economy approach may produce quite different insights than earlier models focusing on benevolent governments that engage in toll and capacity competition. His model assumes that the city government controls a parking fee in the city center, whereas a regional government decides on a cordon toll. Both the city and the regional governments decide by majority voting. Within this setup he shows that road tolls gain less public support than parking fees. Moreover, the paper finds that welfare may be higher when the city and regional government do not coordinate their actions than when they do. The reason is that in an uncoordinated setting charges will be too low compared to the welfare optimum, whereas imperfect coordination raises charges compared to coordinated actions. The latter effect may or may not dominate the former. Given majority voting over transport policies, tax exporting by the city may therefore raise welfare. 


\section{Suggestions for further research}

In this paper, we surveyed the literature on policy competition between governments in the transport sector. In this concluding section, we indicate some topics for future research.

As repeatedly argued in this paper, two main issues deserve especially careful attention in future research. The first one is the clear need for more empirical studies on the welfare effects of tax competition, using realistic and real world information on existing networks. The currently available studies by and large limit applied work to simple illustrative numerical examples. It remains to be seen whether the costs of noncooperative behaviour are substantial or not. Realistic applications with real data are needed to evaluate the welfare effects of non-coordination. The second issue starts from the observation that quite little is known about the political economy of transport pricing and infrastructure decisions in a multi-government world. The large majority of the models discussed in this paper took a normative approach, focusing on policy choices of benevolent, welfare maximizing governments. Such an approach is useful for understanding what policies are welfare-enhancing, but it does not tell us much about the kind of decisions that will come out of the political process. How do countries decide on their tax, toll and capacity investments, and what are the likely outcomes of this process? Which policy instruments are more likely to be observed, and what is the role of regional and federal authorities in pushing certain pricing innovations? Why, despite substantial support from economists, are tolling instruments not frequently used? How are federal funds allocated across regions? Although the first models looking at the political economy of transport decisionmaking have now appeared in the literature, considering these issues in a multigovernment world is still very much underdeveloped, and more research is badly needed. Not only theoretical models, but also detailed case study approaches may be useful in developing this literature. For example, detailed analysis of the political process that has led to the implementation of new pricing and investment tools (London, Stockholm, the kilometre charges in Germany, etc.) may provide substantial new insights.

What are some other remaining challenges? First, there is a clear need to focus on more detailed and realistic pricing instruments. The existing theoretical literature 
implicitly looks at kilometre charges (given tolls or taxes per unit of demand), but the precise distinction between fuel taxes, road tolls, cordon pricing, etc. for the outcomes of governmental competition has not been made. Second, the role of heterogeneity in demand for toll and capacity competition has not been studied in detail. Third, there is the issue of optimal instrument choice by a central government (the EU, federal government in the US, national governments) that is coordinating horizontal competition between member states or regions. Fourth, it seems desirable to carefully study under what conditions there exist possibilities for welfare-improving tax competition in transportation. Fifth, concerning vertical tax competition it is necessary to provide more theoretical insights on the results of vertical tax interaction with realistic pricing instruments (which government controls which instruments, optimal allocation of authority, etc.) and reasonable tax sharing rules. Moreover, the mechanisms available to correct inefficiencies, including various revenue sharing instruments, should be studied in detail.

\section{REFERENCES}

Acemoglu, D. and A. Ozdaglar (2008), Competition in Parallel-Serial Networks, IEEE Journal of Special Areas in Communication, Special Issue on Non-cooperative Behavior in Networking 25, 1180-1192.

Acemoglu, D. and A. Ozdaglar (2007), Competition and Efficiency in Congested Markets, Mathematics of Operations Research 32, 1-31.

Arnott, R. and R. Grieson (1981), Optimal fiscal policy for a state and local government, Journal of Urban Economics 9, 23-48.

Baron D. and J. Ferejohn (1989), Bargaining in legislatures, American Political Science Review 87, 34-47

Bassanini, A. and J. Pouyet (2005), Strategic Choice of Financing Systems in Regulated and Interconnected Industries, Journal of Public Economics 89, 233-259.

Basso, L. and A. Zhang (2007), Congestible facility rivalry in vertical structures, Journal of Urban Economics 61, 218-237. 
Benoot W., J. Brueckner, S. Proost (2012), Intercontinental airport competition, Discussion Paper 12.03 CES-KULeuven

Besley T. and H. Rosen (1998): Vertical externalities in tax setting: evidence from gasoline and cigarettes. Journal of Public Economics 70, 383-98.

Besley T. and S. Coate S. (2003), Centralized versus decentralized provision of local public goods: a political economy approach, Journal of Public Economics, 87, 261137.

Besley, T.(2005) Principled Agents? The Political Economy of Good Government, Lindahl lectures, Oxford University Press.

Bjorner, T. (1996), Any need for coordination of policies towards transit traffic with a negative local externality? Environmental and Resource Economics 8, 221-245.

Black, D. and W. Hoyt (1989), Bidding for firms, American Economic Review 79, 1249-1256.

Boadway, R., Marchand, M and M. Vigneault (1998), The consequences of overlapping tax bases for redistribution and public spending in a federation, Journal of Public Economics 68, 453-478.

Boadway, R. and A.Shah (2009), Fiscal federalism - principles and practice of multiorder governance, Cambridge University Press, $620 \mathrm{p}$

Bond, E. (2006), Transportation infrastructure investments and trade liberalization, The Japanese Economic Review 57 (4), 483-500.

Braid, R. (1996), Peak-load pricing of a transportation route with an un-priced substitute, Journal of Urban Economics 40, 179-197.

Brueckner, J.K. (2002), Airport congestion pricing when carriers have market power. American Economic Review 92, 1357-1375.

Brueckner, J.K. (2005), Internalization of airport congestion: A network analysis, International Journal of Industrial Organization 23, 599-614.

Bucovetsky, S and J. Wilson (1991), Tax competition with two tax instruments, Regional Science and Urban Economics 21(3), 333-350.

Cantos-Sanchez, P., R. Moner-Colonques, J.J. Sempere-Monerris and O. AlvarezSanJaime (2010), Vertical Integration and Exclusivities in Maritime Freight Transport, Working paper, University of Valencia, Spain.

Caselli, F. and F. Morelli (2004), Bad politicians, Journal of Public Economics 88 (34), 759-782.

Dahlby, B. (1996), Fiscal externalities and the design of intergovernmental grants, International Tax and Public Finance 3, 397-412. 
De Borger, B., Courcelle, C. and D. Swysen (2004), Optimal pricing of transport externalities in an international environment: empirical evidence based on a numerical optimisation model, Regional Science and Urban Economics 34, 163-201.

De Borger, B. and D. De Bruyne (2011), Port Activities, Hinterland Congestion, and Optimal Government Policies: The Role of Vertical Integration in Logistic Operations, Journal of Transport Economics and Policy, 45(2), 247-275.

De Borger, B., Dunkerley, F. and S. Proost (2007), Strategic investment and pricing decisions in a congested transport corridor. Journal of Urban Economics 62, 294-316.

De Borger, B., Dunkerley, F. and S. Proost (2008), The interaction between tolls and capacity investment in serial and parallel transport networks. Review of Network Economics 7, 1-23.

De Borger, B., Ochelen, S., Proost, S. and D. Swysen (1998), Regional and federal interests in transport and environment policy-making: the case of Belgium, in S. Proost and J. Braden, Climate change, Transport and Environmental policy, Edgar Elgar, 221-243.

De Borger, B. and W. Pauwels (2010), A Nash bargaining solution to models of taks and investment competition: tolls and investment in serial transport corridors, IEB working paper 2010/1, Universidad de Barcelona.

De Borger, B. and S. Proost (2012 a), A political economy model of road pricing, Journal of Urban Economics 71, 79-91.

De Borger, B. and S. Proost (2012 b), Policies to reduce traffic externalities in cities, Discussion Paper

De Borger, B., Proost, S. and K. Van Dender (2005), Congestion and tax competition in a parallel network, European Economic Review, 49, 2013-40.

De Borger, B., Proost, S. and K. Van Dender. (2008,), Private port pricing and public investment in port and hinterland capacity, Journal of Transport Economics and Policy 42 (3), 1-35.

De Borger, B. and K. Van Dender (2006), Prices, capacities and service levels in a congestible Bertrand duopoly, Journal of Urban Economics, 60, 264-283.

de Palma, A., Leruth, L., 1989. Congestion and game in capacity: a duopoly analysis in the presence of network externalities. Annales d'Economie et de Statistique 15/16, $389-407$.

de Palma, A. and R. Lindsey (2000), Private toll roads: a dynamic equilibrium analysis, Annals of Regional Science, 34, 1, 13-35.

de Palma, A. and R. Lindsey (2000), Private toll roads: competition under various ownership regimes, The Annals of Regional Science 34, 13-35. 
de Rus, G. and M. Socorro (2010), Infrastructure Investment and Incentives with Supranational Funding, Transition Studies Review 17(3), 551-567.

Devereux, M.P., Lockwood, B. and M. Redoano (2007), Horizontal and vertical indirect tax competition: Theory and some evidence from the USA, Journal of Public Economics 91, 451-479

Glazer, A. and S. Proost (2010), Reducing rent seeking by providing wide public service, CES - Discussion paper series DPS10.31, KULeuven CES

Hoyt, W. (2001), Tax Policy coordination, vertical externalities and optimal taxation in a system of hierarchical governments, Journal of Urban Economics 50, 491-516.

Janeba, E. (1998), Tax competition in imperfectly competitive markets, Journal of International Economics 44, 135-153.

Kanbur, A. and M. Keen (1993), Jeux sans frontières: tax competition when countries differ in size, American Economic Review 83, 877-892.

Keen, M. and C. Kotsagiannis (2003), Leviathan and capital tax competition in a federation, Journal of Public Economic Theory 5, 177-199.

Kehoe, P. (1989), Policy coordination among benevolent governments may be undesirable, Review of Economic Studies 56, 289-296.

King, D., Manville, M. and D. Shoup (2007), The political calculus of congestion pricing, Transport Policy 14, 111-123.

Knight, B. (2004), Parochial interests and the centralized provision of local public goods: evidence from congressional voting on transportation projects, Journal of Public Economics 88, 845-866.

Levinson, D. (2001), Why states toll - An empirical model of finance choice, Journal of Transport Economics and Policy, 35, 2, 223-238.

Levinson, D. (2000), Revenue choice on a serial network, Journal of TransportEconomics and Policy 34, 69-98.

Lévy-Lambert, H. (1968), Tarification des services à qualité variable: application aux péages de circulation, Econometrica 36, 564-574.

Liu, L. and J.F. McDonald (1998), Efficient congestion tolls in the presence of unpriced congestion: a peak and off-peak simulation model, Journal of Urban Economics 44, 352-366.

Liu, L. N. and J. F. McDonald (1999), Economic Efficiency of Second-Best Congestion Pricing Schemes in Urban Highway Systems, Transportation Research Part B 33,157-88. 
Lockwood, B. (2006), The political economy of decentralization, in Ahmad, E. and G. Brosio, Handbook on fiscal federalism, Edgar Elgar.

Marchand, M. (1968), A note on optimal tolls in an imperfect environment. Econometrica 36, 575-581.

Marcucci, E., Marini, M. and D. Ticchi (2005), Road pricing as a citizen-candidate game, European Transport 31, 28-45.

McDonald, J.F. (1995), Urban highway congestion: an analysis of second-best tolls, Transportation 22, 353-369.

Mintz, J. and H. Tulkens (1986), Commodity taxation between member states of a federation: equilibrium and efficiency, Journal of Public Economics 29, 173-197.

Mun, S. and K. Ahn (2008), Road pricing in a serial network, Journal of Transport Economics and Policy 42, 367-395.

Mun, S. and S. Nakagawa (2008), Cross-border transport infrastructure and aid policies, Annals of Regional Science 42, 465-486.

Mun, S. and S. Nakagawa (2010), Pricing and investment of cross-border transport infrastructure, Regional Science and Urban Economics 40, 228-240.

Nash, C. (2005), Rail infrastructure charges in Europe, Journal of Transport Economics and Policy 39, 259-278.

Oates, W. (1972), Fiscal federalism, Harcourt, Brace Jovanovich, New York.

Pels, E. and E. Verhoef (2004), The economics of airport congestion pricing, Journal of Urban Economics 55(2), 257-277.

Proost, S. and A. Sen (2006), Urban transport pricing reform with two levels of government: a case study of Brussels, Transport Policy 13, 127-139.

Proost, S., Dunkerley F., Van der Loo S., Adler N., Bröcker J., Korzhenevyc A., (2010), Do the selected Trans European transport investments pass the Cost Benefit test?, CES discussion paper 10.02

Proost, S. and V. Zaporozhets (2010), The political economy of fixed regional investment shares with an illustration for Belgian Railway investments, CES discussion paper 2010.05

Proost, S., Dunkerley, F., De Borger, B., Günhneman, A., Koskenoja, P., Mackie, P., van der Loo, S. (2011). When are subsidies to trans european network projects justified?. Transportation Research A, Policy and Practice, 45(3), 161-170

Rietveld, P. and S. van Woudenberg (2005), Why fuel prices differ. Energy Economics 27, 79-92. 
Rosenbloom, S. and M? Wachs (2012), A Federal Role in Freight Planning and Finance. Santa Monica, CA: RAND Corporation, 2012. http://www.rand.org/pubs/monographs/MG1137.

Rork, J.C. (2009), Yardstick competition in toll revenues: evidence from US states, Journal of Transport Economics and Policy 43, 123-139.

Russo, A. (2012), Voting on road congestion policy, in Three Essays in Public Economics, Ph.D. thesis, Toulouse.

Small, K. and J. Yan (2001), The value of "Value Pricing" of roads: second best pricing and product differentiation, Journal of Urban Economics, 49, 2, 310-336.

Small, K. and E. Verhoef (2007): The Economics of Urban Transportation, second edition, Harwood Fundamentals of Pure and Applied Economics Series, Routledge.

Tiebout, C (1956), A pure theory of local expenditures, Journal of Political Economy, 64: 416-24.

Tirole J. (1988), The Theory of Industrial Organisation, MIT press.

Ubbels, B. and E. Verhoef (2008), Governmental Competition in Road Charging and Capacity Choice, Regional Science and Urban Economics, 38, 174-190.

Upman, T. (1998), Two games of interjurisdictional competition when local governments provide industrial public goods, International Tax and Public Finance 5, 471-488.

van den Berg, V.A.C. and E. Verhoef (forthcoming 2012), Is the travel time of private roads too short, too long, or just right?, Transportation Research B.

Van Dender, K. (2004), Pricing transport networks with fixed residential location, Regional Science and Urban Economics 34, 289-307.

Van Dender, K. (2005), Duopoly prices under congested access, Journal of Regional Science 45, 343-362.

Van der Loo, S. and S. Proost (2011), The European road pricing game: how to enforce optimal pricing in high-transit countries under asymmetric information, CES DP 11.19

Verhoef, E. (2002), Second-Best Congestion Pricing in General Networks: Heuristic Algorithms for Finding Second-Best Optimal Toll Levels and Toll Points, Transportation Research Part B 36, 707-29.

Verhoef, E. (2007), Second-best Road Pricing through Highway Franchising, Journal of Urban Economics 62, 337-61.

Verhoef, E. (2008), Private roads: Auctions and competition in networks, Journal of Transport Economics and Policy 42, 463-493. 
Verhoef, E. and J. Rouwendal (2004), Pricing, Capacity Choice, and Financing in Transportation Networks, Journal of Regional Science 44, 405-35.

Verhoef, E. and K. Small (2004), Product differentiation on roads: second-best congestion pricing with heterogeneity under public and private ownership, Journal of Transport Economics and Policy 38, 127-156.

Verhoef, E., Nijkamp, P. and P. Rietveld (1996), Second-best congestion pricing: the case of an untolled alternative, Journal of Urban Economics 40, 279-302.

Viton, P. (1995), Private Roads, Journal of Urban Economics, 37, 260-89.

Wan, Y. and A. Zhang (forthcoming 2012), Urban road congestion and port competition, Journal of Transport Economics and Policy.

Westin J., Franklin J, Grahn-Voorneveld S., and S. Proost, (forthcoming), How to decide on regional infrastructure to achieve intra-regional acceptability and interregional consensus?, Papers in Regional Science

Wildasin, D. (1989), Interjurisdictional capital mobility: fiscal externality and a corrective subsidy, Journal of Urban Economics 25, 193-213.

Wildasin, D. (1988), Nash equilibria in models of fiscal competition, Journal of Public Economics 35, 229-240.

Wilson, J. (1999), Theories of tax competition, National Tax Journal 52, 269-304.

Wu, D., Yin, Y. and H. Yang (2011), The independence of volume-capacity ratio of private toll roads in general networks, Transportation Research B 41(1), 96-101.

Xiao, F., H. Yang, and D. Han (2007), Competition and Efficiency of Private Toll Roads, Transportation Research B 41, 292-308.

Yang, H. and Meng, Q. (2000), Highway pricing and capacity choice in a road network under a build-operate-transfer scheme, Transportation Research A 34, 207222.

Yang, H., Tang, W.H., Cheung, W.M. and Q. Meng (2002), Profitability and welfare gain of private toll roads in a network with heterogeneous users Transportation Research Part A 36, 537-554.

Yuen, A., L. Basso and A. Zhang (2008), Effects of Gateway Congestion Pricing on Optimal Road Pricing and Hinterland, Journal of Transport Economics and Policy 42(3), 495-526.

Yuen, A. and A. Zhang (2007), Port Pricing in a Congestible Intermodal Transport System, paper presented on the International Conference on Logistics, Shipping and Port Management, Kainan University Taiwan, 29-30 March. 